\title{
8 Ligeti and the beginnings of Bartók analysis in Hungary
}

\author{
Anna Dalos
}

It is a well-known fact that after his 1956 emigration György Ligeti wanted to break with Hungarian musical tradition, especially with Bartók’s legacy. ${ }^{1}$ Though he was terribly homesick, as Rachel Beckles Willson points out, he did not publicly mention his relation to Hungary for twelve years. ${ }^{2}$ However, Ligeti's writings and radio lectures, above all his Bartók analyses written between 1957 and 1961, reveal much of his relation to the recent past. As he told Péter Várnai in an interview in 1979, his alienation from Bartók had begun already in 1955 before his emigration. ${ }^{3}$ Under the new circumstances experienced in the West, this process was reinforced with his turn towards Anton Webern's music. ${ }^{4}$ It is clear that Ligeti did not want to be a 'Bartók-boy', that is a socially disadvantaged emigrant Hungarian composer in Cologne or Darmstadt, but aspired to be regarded as a colleague of equal rank. As a result, he consciously avoided opportunities when he could have presented himself as a Bartók expert: in all probability he accepted such invitations only if he needed money. This is how his foreword to the pocket score of Bartók's String Quartet no. 5 (1957), ${ }^{5}$ his radio lecture on Mikrokosmos (around 1959) ${ }^{6}$ and another two-part radio lecture on Bartók's harmony (in 1961) came into existence. ${ }^{7}$

Ligeti's custom of measuring every single musical feature in an analysis of Bartók's music, which was typical of the Hungarian musicians' circles, can be seen in his Webern lectures. Other signs indicating that Ligeti tried to use analytical devices acquired in Hungary are his constant references to a piece of musicological literature which did not come up in the discussions of the Darmstadt avant-garde. Speaking about symmetrical structures in new music, he referred in his Webern lectures to Bartók’s Music for Strings, Percussion and Celesta, linking Webern's compositional devices to those of Bartók. ${ }^{8}$ Ligeti even mentioned Knud Jeppesen's books on counterpoint, ${ }^{9}$ a core of Hungarian composers' curriculum, ${ }^{10}$ but by no means a part of the basic literature on serialism. Ligeti's reference to Ernö Lendvai's Bartók analysis in his lecture on Bartók's harmony in 1961 must have had a similarly surprising effect, for Lendvai's theory was absolutely unknown in Western Europe at that time. ${ }^{11}$ These references could be understood as signs of the earlier Hungarian context in a transitional period. Ligeti had to relearn everything after 1956; he had to acquire the skill to look at music with new eyes, to approach music absolutely differently from what he had been used to. To a certain extent he had to undergo 'brainwashing'. His understanding of Bartók's music as well as his 
readings of Lendvai or Jeppesen had formed essential parts of his earlier life and had functioned as fundamentals of his craftsmanship up to 1956, which he could not forget from one day to the next.

This rupture with his past had certain psychological consequences as well: it was part of Ligeti's self-distancing from Bartók that he stressed the weaknesses of some of Bartók's compositional ideas and technical solutions. In fact, Ligeti criticized exactly the same works - those from Bartók's last period ${ }^{12}$ - that he had characterized a few years earlier, in agreement with the contemporary Hungarian reception, as 'the peaks of modern music'.$^{13}$ Ligeti consciously stressed that he agreed even with René Leibowitz's accusation that Bartók had made a compromise in his late works. ${ }^{14}$ While in Ligeti's view Bartók's music brought something new to compositional thinking with regard to melody and harmony, rather than the use AuQ20 of symmetrical structures, his forms represented a kind of provincial attitude. ${ }^{15}$ This was due to Bartók's traditional composition practice based on Beethoven's technique of development, particularly if these forms are compared with Stravinsky's oeuvre. ${ }^{16}$ According to Ligeti, Bartók insisted on closed, periodical forms and believed in traditional musical materials, in spite of the fact that this material was impaired in the hands of Bartók's contemporaries. Ligeti's formulation - 'the musical material was impaired' ${ }^{17}$ - and his other wording accusing Bartók of turning his late works into 'consumer goods' ${ }^{18}$ refer unambiguously to Adorno's theories on new music and the music market. ${ }^{19}$

His deliberate distancing of himself from his former ideal led later to suppressions in connection with his Hungarian heritage. In the interview given to Péter Várnai in 1979 Ligeti identified Ernő Lendvai's Bartók analyses with the theory of golden section, although he must have been aware that golden section theory was but one of Lendvai's analytical devices. Remembering Lendvai's theory Ligeti recalled his own experiments with the golden section, which proves again that Ligeti tried to reconcile his earlier experiences with the new information gathered in Cologne and Darmstadt in the transitional period between 1957 and 1961:

I was greatly influenced by the prevailing mood among musicians in Cologne and Darmstadt. I felt the need to work out the construction of my works with great precision. I was in complete agreement with Ernő Lendvai's Bartók analysis. (Just for the record; in the Cologne studios I tried to apply the principle of the golden section to my work with partials. The result was senseless and it sounded awful.) Since then, I have to come to the conclusion that the golden section is only one of several formal divisions that are neither quite symmetrical nor quite asymmetrical. In the first movement of Apparitions, I applied Bartók's golden section as interpreted by Lendvai. Its first part is in a low register and the second in a high register; the relative duration of the two parts corresponds to the proportions of the golden section. Subsequent shorter parts of the movement are also divided in the same proportion. The golden section is in fact the dominant formal principle of the work. Looking back on it, I must say that I could have applied any other principle of proportions just as well. ${ }^{20}$ 
Ligeti's statement plays down the importance of his experiments with the golden section, and describes them as an error, or at least as a lower stage of his development. But he fails to mention that his experiment was in full agreement with the practice of contemporary Hungarian composers, who interpreted Lendvai's 1955 book on Bartók's style as a starting point to fecundate 'Hungarian serial music' with the spirit of Bartók’s music. ${ }^{21}$

In point of fact, Ligeti never denied that Lendvai's theory had had a great impact on him. Both of the two young musicians, of the same age, participated in the shaping of Hungarian Bartók interpretation after the composer's death. They both attended Bence Szabolcsi's Bartók seminar at the Academy of Music; their first analytical studies on Bartók, published in 1947 and 1948 respectively, were elaborated and discussed there. ${ }^{22}$ For the young Ligeti Szabolcsi was 'the crystallization point of the new Hungarian school', as he was 'the most important adviser and the highest authority on all musical issues'. ${ }^{23}$

Based on the composer's personal recollection, Friedemann Sallis pointed out that Ligeti's enthusiasm for Szabolcsi decreased in the following years because of the musicologist's 'political opportunism', as Ligeti put it, and his role as the 'eminence grise' of the hard-line communist music journal, Új Zenei Szemle (New Music Review). ${ }^{24}$ To understand Ligeti's criticism of Szabolcsi one has to comprehend the function of Bartók's image in the circle of progressive intellectuals in Hungary. After leaving his homeland in the autumn of 1940 Bartók soon became a symbol of freedom and ethical purity in the collective memory, an image also reinforced by his premature death on 26 September 1945 . This was how the socalled Bartók model came into being. ${ }^{25}$ Hungarian musicians, old and young alike, acquired a profound knowledge of Bartók's oeuvre or rather the part one could get acquainted with at that time. Nevertheless, Bartók's music as a 'national matter' became a constant topic of discussion among progressive musicians. Bartók was alive in many musicians' memory, even though his figure faded during his fiveyear emigration. But there was also a new generation of composers, performers and musicologists who did not know him personally any more. For them Bartók AuQ21 was a historical figure, whose music was no longer self-explanatory but something that had to be interpreted. These young musicians, like Ligeti and Lendvai, were, however, fully aware that Bartók's oeuvre would determine the direction of the new Hungarian music. As a result, Hungarian Bartók analysis had a triple function: in addition to forming a general understanding of Bartók it helped performers to interpret Bartók’s works in agreement with their poetic content, ${ }^{26}$ and, at the same time, showed composers the direction towards a new tonality based on twelve tones. $^{27}$

The leading music journal of this early period between 1945 and 1948, Zenei Szemle (Music Review), published several unknown documents on Bartók's life as well as articles that interpreted stylistic issues in the composer's oeuvre. Ligeti's and Lendvai's first writings were of this latter type. Both made an effort to develop a kind of 'close reading' in Hungary. Their interpretations belong to the family of twentieth-century structural analyses and can be understood as parallel phenomena with the American 'pitch class set' analysis that tried to prove, among others, that 
there were serial implications in Bartók's music. ${ }^{28}$ With his analysis Lendvai aimed at demonstrating that Bartók's method of composition was of equal rank at the very least, if not superior, to Schoenberg's dodecaphony. ${ }^{29}$ Lendvai wanted to prove that Bartók's compositional method was completely systematic, which meant for him that Bartók was able to combine tonal and atonal thinking. According to Lendvai, the ability to reconcile those two principles allowed Bartók to get the upper hand over the second Viennese school.

The view of the supremacy of new Hungarian music due to Bartók's genius is apparent not only in Lendvai's analyses but in other Hungarian Bartók interpretations as well. However, it is clear from Ligeti's recollections that Hungarian musicians did not understand the principle of dodecaphony at that time. As he put it,

I did not know Schoenberg or Webern but had heard about their music and worked out a kind of pentatonic serialism. The series consisted of two pentatonic scales - with two pien notes they add up to twelve. ${ }^{30}$

One has to admit that it is not only this misinterpretation of dodecaphony that distinguishes the young Hungarians' analyses from other structuralist conceptions. Characteristic of Lendvai's and Ligeti's analyses is that they strive to interpret Bartók's compositional technique by hermeneutical means as well: they ask for the meaning of Bartók's chordal structures, forms and periodicity. Extramusical inspirations play a significant role in their interpretations. Such inspirations would have been unimaginable in either the writings of István Szelényi, the most prolific Bartók analyst of the time, or the studies of the Darmstadt circle or the American set theorists.

The most decisive literary inspiration must have been Sigmund Freud's collection of four essays entitled Totem und Tabu (Totem and Taboo), published in $1913 .{ }^{31}$ Lendvai cites the book in his study on Bartók's style, ${ }^{32}$ and József Ujfalussy mentions Lendvai's Freudian inclination even in the 1955 Lendvai debate in a derogatory sense. ${ }^{33}$ We know from György Kurtág's recollections that Totem und Tabu was one of Ligeti's main readings at the end of the 1940s. ${ }^{34}$ It is not hard to understand why young Hungarian intellectuals turned to Freud's theory: Freud's work is about breaking taboos, about the reasons for violating basic ancestral rules, about the murderer in us, about the survivors' consciousness of guilt and neurosis that makes it possible to go on living, in short, about emotional defects that could be experienced during and after World War II. For Ligeti, who lost both his beloved father and brother in 1944, the reading of Freud's theory must have helped in the process of coping with and overcoming the loss.

Young Hungarian analysts nevertheless make direct reference to Freud's book only incidentally. Much more often they speak about a primitive or an ancestral tone, which breaks into an idealistic world of the nineteenth century. Ligeti formulated this unambiguously in his analysis of Bartók’s Bear Dance in 1948, and his reference to Freud's theory is hardly disputable:

This is the moment, when Europe, over-ripe, a glass-encaged silver rose mere soft lace, trips in a charabanc, the memories of a childhood taste of tea 
cakes - is suddenly broken into by wolves, bears, by the eerie world of steppes and taigas - where do they come from; from which steppes and forests; from the far east or perhaps even deeper, from the primeval forest, the long forgotten, haunted darkness of our soul.

No matter: Bartók conjured up something for which no one before had the courage, the buried, unacknowledged world, the 'sprawling on sand' world of 'contemplation', the noisy, revelling, embracing, murderous, aggressive world of magic, dreams, totem worship. ${ }^{35}$

This section quotes not only Freud but other literary and musical models as well, such as Richard Strauss's Der Rosenkavalier or Marcel Proust's À la recherche du temps perdu. According to Kurtág the latter was another favourite reading of Ligeti's at the time. ${ }^{36}$ More importantly, the style of the above section resembles in an astonishing manner Bence Szabolcsi's literary style, particularly that of his 1940 book A zene története (The History of Music). ${ }^{37}$ Ligeti’s analysis of Bartók’s Bear Dance, published, remarkably, while he was still a student at the Academy of Music, bears the signs of a successfully done homework.

Ligeti even cites Ernst Kurth's theory, which was a standard work for all Hungarian pupils of composition and teachers who followed Kodály's instructions. ${ }^{38}$ Ligeti, who from the early 1940s had been familiar with Kurth's Musikpsychologie, his book on the Tristan-chord and his theory of Bachian counterpoint, ${ }^{39}$ concentrated in his analysis on Bartók's use of dissonances. Dissonances are phenomena that need explanation in this context, as they are strange or disturbing to the average listener. Ligeti tries to prove that Bartók's chromaticism originates from the pentatonic scale as Bartók never wrote twelve-tone music, his compositional thinking is rooted firmly in the diatonic or pentatonic tradition, and "the chromatic flavour [in his compositions] is produced merely with freely manipulated, often simultaneously appearing small and large appoggiaturas'. ${ }^{40}$ In Ligeti's view, the chromaticism of some pieces of Mikrokosmos is nothing but a compressed pentatonic scale. ${ }^{41}$ While the former statement is but a reformulation of Kodály's 1921 explanation of Bartók's dissonances influenced by Kurth's theory as well, ${ }^{42}$ the latter is in full concordance with Ligeti's above-mentioned reference to his own experiments with pentatonic dodecaphony. ${ }^{43}$

After 1948 events unexpectedly took a turn for the worse: the communist takeover changed the climate not only in politics and everyday life, but also, following the Zhdanovian directives, in cultural life. Bartók's oeuvre was reinterpreted and re-evaluated in the light of the new, communist ideology, and this reinterpretation led to the much-debated 'Bartók-case' around $1950 .{ }^{44}$ The change cast a shadow over the recently emerged discipline of Hungarian Bartók analysis, leading to its disappearance from musical discourse for a while. In the issues of Új Zenei Szemle (New Music Review) almost ninety papers on Bartók (documentary editions, philological essays, ideological interpretations) were published between 1950 and 1956 but only seven of them were analytical studies, written without exception for the Lendvai debate, initiated by the senior editor of the journal, István Szelényi, in $1955-6 .{ }^{45}$ It is telling that three of the seven studies were by him. ${ }^{46}$ 


\section{Anna Dalos}

Between 1948 and 1955, during a decisive period of his artistic maturation, the composer's views changed considerably. As a result, his 1948 analysis of the Bear Dance and his 1955 study on Bartók's chromaticism cannot be claimed to be of identical specific gravity. The same can be said of Ernő Lendvai's writings. Their mentality changed gradually after 1948, but this change, the deviation from the official mainstream, became manifest only in the Lendvai debate of 1955 when Lendvai's theory - above all his new book on Bartók's style - was attacked in both ideological and musical respects. Both Ligeti and Lendvai abandoned 'Freudian' interpretations. Instead, Lendvai began interpreting works of art as natural phenomena in which every event derives from the conditions of nature. ${ }^{47}$ Thus, Bartók’s music represented real life, nature, and, at the same time, conjured up the other, extra-natural or supernatural world. Lendvai's view resulted in his political and professional discrediting; he was relegated to the periphery of musical life. ${ }^{48}$ Ligeti's deviation was not so severely punished. The editors of Új Zenei Szemle only supplemented with a footnote Ligeti's study on the circumstances of the development of Bartók's chromaticism written in defence of Lendvai: 'This interesting explanation of Bartók's music is to be regarded momentarily as a topic of debate. ${ }^{49}$

Up to this point Ligeti had progressed smoothly up the hierarchy of Hungarian musical life, due partly to the support of the greatest living authority, Zoltán Kodály..$^{50}$ Ligeti was teaching at the Academy of Music and published tutorials on classical harmony. ${ }^{51}$ When at the age of thirty-two he published his study on Bartók's chromaticism he was already in a position to appear with self-assurance and to manifest himself as a skilled expert on Bartók. Rachel Beckles Willson points out, however, that Ligeti appears in this study as a representative of Hungarian 'national apologists' who gave voice to the contemporary Hungarian view when he positioned Bartók above Schoenberg. ${ }^{52}$ In reality he relied on other sources than his contemporaries when he appreciated Bartók as the most relevant composer of the twentieth century.

In his study Ligeti takes undoubtedly sides with Lendvai, but Adorno's Philosophy of New Music, which Ligeti acquired at that time, ${ }^{53}$ influenced him more. Ligeti's writing resembles the complicated structure of Adorno's German philosophical language, which gives the impression of clumsiness in Hungarian. Sometimes Ligeti even uses hidden quotations from Adorno's text, for example when he speaks about the possibility of the dissolution of dodecaphony through contrapuntal thinking or the formal-structural problems caused by the disappearance of tonality. ${ }^{54}$ These might have seemed indeed 'interesting explanations' for those of Ligeti's Hungarian contemporaries who did not know Adorno's book. It is, however, evident that Ligeti was no longer interested in the meaning of Bartók's music. Hermeneutics disappeared from his set of devices.

It must have been due to Adorno's influence that Ligeti realized his alienation from Bartók:

Then, in the early '50s I began to feel that I had to go beyond Bartók. It did not mean repudiating him, of course; stylistically, I have always maintained very 
strong links with him. What I felt I had to abandon were traditional forms, a musical language of the traditional kind, the sonata form [. . .]. I wanted to get away from all ready-made forms, which Bartók took seriously, and had learned from late Beethoven and from Liszt. Bartók's sonorities were still valid for me, also his chromaticism, but I had to get beyond formal structure as used by Bartók, and here I mean not only the overall structural forms but also the small formal elements of a composition..$^{55}$

Ligeti's recollection is completely in agreement with his Bartók studies written after his emigration and hints at the same compositional difficulties - the traditionalism of the formal thinking - that he stressed in his 1961 radio lecture on Bartók's harmony. Ligeti tried to find a new way of creating musical forms for which he could not regard Bartók's music as a model any longer. Adorno's book, however, suggested a possible solution that stirred his imagination. In his 1955 Bartók article Ligeti refers to it in connection with the technique of development: 'development no longer exists, form becomes static, for all intents and purposes, it stands outside of time' ${ }^{56}$ Later, Ligeti strove for the ideal of this kind of static music without time for some years, but at that time, in 1955, he had no means to realize it. This implies that his study on Bartók's chromaticism not only is a document of the history of Hungarian Bartók analysis, but should be regarded as one of the first sources of the changes in Ligeti's compositional thinking that led him to a new, Western-oriented creative phase after 1956. The transitional period that ended with Ligeti's total assimilation to new Western music began in Budapest in the mid-1950s. Bartók's music lost its significance for Ligeti for the next twenty years, but its interpretation as an essential source of Ligeti's stylistic change survived the cataclysm.

\section{Notes}

1 Nordwall/Ligeti, pp. 56-7. Richard Steinitz puts Ligeti's dissatisfaction with the Bartókian style around 1950; see Steinitz/Ligeti, p. 53.

2 Rachel Beckles Willson, 'Reconstructing Ligeti', in Music's Intellectual History, ed. Zdravko Blažeković and Barbara Dobbs Mackenzie (New York: Répertoire International de Littérature Musical, 2009), pp. 443-8, at 444.

3 Péter Várnai, Beszélgetések Ligeti Györggyel [Conversations With György Ligeti] (Budapest: Zenemúkiadó, 1979), pp. 15-16; English translation in Ligeti/Conversation, p. 13.

4 Ligeti planned to write a book about Webern at the end of the 1950s and at the beginning of the 1960s; see Monika Lichtenfeld: 'Komposition und Kommentar: György Ligetis Kunst des Schreibens', in GS I, pp. 9-42, at pp. 13-14; and Chapter 10 of this volume.

5 Ligeti, 'Bartóks Fünftes Streichquartett: Eine Analyse', in GS I, pp. 315-17.

6 Ligeti, 'Über Bartóks Mikrokosmos', in GS I, pp. 318-21.

7 'Über Bartóks Harmonik', in GS I, pp. 302-8.

8 Ligeti, 'Über die Harmonik in Weberns Erster Kantate', in GS I, pp. 395-410, see especially p. 399.

9 Lichtenfeld, 'Komposition und Kommentar', p. 14. Knud Jeppesen, Der Palestrinastil und die Dissonanz (Leipzig: Breitkopf \& Härtel, 1925), and Kontrapunkt: Lehrbuch der klassischen Vokalpolyphonie (Leipzig: Breitkopf \& Härtel, 1935).

10 Anna Dalos, 'Miért éppen Jeppesen? Kodály és az ellenpont-tankönyvek' [Why Jeppesen? Kodály and the Counterpoint Books], Magyar Zene 38/1 (January 2000), pp. 5-26. 


\section{Anna Dalos}

11 Ernő Lendvai, Bartók stílusa a „Szonáta két zongorára és ütőhangszerekre” és a „Zene húros, ütö-hangszerekre és celestára” tükrében [Bartók's Style as Reflected in the Sonata for Two Pianos and Percussion and the Music for Strings, Percussion and Celesta] (Budapest: Zenemükiadó, 1955). Lendvai's writings were translated into German and English relatively late: Über die Formkonzeption Bartóks (Budapest: Akadémiai, 1969), Béla Bartók: An Analysis of His Music (London: Kahn and Averill, 1971) and Bartók and Kodály (Budapest: Institute for Culture, 1976).

12 'Über Bartóks Harmonik', p. 307.

13 'Diese Werke sind ein Gipfel der modernen Musik.' See György Ligeti, 'Neue Musik in Ungarn', in GS I, pp. 51-5, here p. 52.

14 'Über Bartóks Mikrokosmos', p. 320.

15 Ligeti, 'Bartók harmóniavilágáról', in Ligeti György válogatott írásai [Selected Writings of György Ligeti], ed. Márton Kerékfy (Budapest: Rózsavölgyi, 2010), pp. 78-90. Kerékfy published Ligeti's whole lecture, while only its second part was published in Lichtenfeld's edition; see 'Über Bartóks Harmonik', pp. 302-8.

16 'Bartók's and Stravinsky's relate themselves differently to the tradition, as Bartók treats his heterogeneous musical material with the traditional technique of motivic development. Bartók's harmonic and melodic world is modern; his forms are, however, conservative.' 'Bartók harmóniavilágáról', p. 81.

17 'Bartók harmóniavilágáról', p. 82.

18 'Bartók harmóniavilágáról', pp. 80-1.

19 See Adorno's study on the fetish character of music: 'Über den Fetischcharakter in der Musik und die Regression des Hörens', Zeitschrift für Sozialforschung 7/3 (1938), pp. 321-56. In English: 'The Fetish-Character in Music and the Repression of Listening', in The Essential Frankfurt School Reader, ed. Andrew Arató and Eike Gebhardt (New York: The Continuum Publishing Company, 1985), pp. 270-99.

20 Ligeti/Conversation, p. 43.

21 Anna Dalos, 'Bartók, Lendvai und die Lage der ungarischen Komposition um 1955', SM 47/3-4 (2006), pp. 427-39.

22 Ernő Lendvai, 'Bartók: "Improvisations" sorozatáról. (1920)' [About Bartók’s Improvisations (1920)], Zenei Szemle 3 (1947), pp. 151-67; and 'Az éjszaka zenéje (elemzés)' [The Night's Music (an analysis)], Zenei Szemle 4 (1947), pp. 216-19. György Ligeti, 'Bartók: Medvetánc (1908)' [Bartók: Bear Dance (1908)], Zenei Szemle 5 (March 1948), pp. 251-5; rep. in GS I, pp. 309-14. That Lendvai and Ligeti presented their analyses for the first time at Szabolcsi's Bartók seminar is mentioned by György Kurtág in his recollections; see Bálint András Varga, Kurtág György (Budapest: Holnap, 2009), p. 144.

23 Ligeti, 'Neues aus Budapest: Zwölftonmusik oder "Neue Tonalität”?', in GS I, p. 48.

24 Sallis/Ligeti, pp. 38-9.

25 See Danielle Fosler-Lussier, Music Divided: Bartók's Legacy in Cold War Culture (Berkeley: University of California Press, 2007). For the Hungarian reception of the 'Bartók model' see 'Bartók nem alkuszik', in Dénes Zoltai, Bartók nem alkuszik - avagy az úgynevezett esztétikai kompromisszumról [Bartók Does Not Bargain: About the Socalled Aesthetical Compromise] (Budapest: Magvető, 1978), pp. 136-53.

26 See the recollections of Lendvai's widow, the pianist Erzsébet Tusa: . . . szigetre mentett magvak. . . [Seeds Saved to an Island] (Budapest: Eötvös József Alapítvány, 1993), p. 20.

27 See Dalos, 'Bartók, Lendvai und die Lage der ungarischen Komposition'.

28 See the American reception of Lendvai's books: Roy Howat, 'Bartók and the Principles of Proportional Analysis', MA 2/1 (March 1983), pp. 69-95; Malcolm Gillies, 'E. Lendvai: The Workshop of Bartók', MA 5/2-3 (July-October 1986), pp. 285-95; Elliott Antokoletz, 'Theories of Pitch Organisation in Bartók's Music: A Critical Evaluation', International Journal of Musicology 7 (1998), pp. 259-300. 
29 See Dalos, 'Bartók, Lendvai und die Lage der ungarischen Komposition', pp. 430-1.

30 Ligeti/Conversation, pp. 47-8.

31 Sigmund Freud, Totem und Tabu: Einige Übereinstimmungen im Seelenleben der Wilden und der Neurotiker (Leipzig: Hugo Heller \& Cie, 1913).

32 Lendvai, Bartók stílusa, p. 80.

33 József Ujfalussy, 'Számarányok Bartók zenéjének szerkesztésében (Megjegyzések Lendvai Ernő könyvéhez)' [Numerical Proportions in the Structures of Bartók Music (Observations on Ernő Lendvai's Book)], UZSz 6/11 (1955), pp. 1-7, at p. 7.

34 Varga, György Kurtág, p. 143.

35 Ligeti, 'Bartók: Medvetánc (1908)', p. 251; reprinted in GS I, p. 309.

36 Varga, György Kurtág, p. 143.

37 Bence Szabolcsi, A zene története (Budapest: Rózsavölgyi, 1940).

38 See Anna Dalos, Forma, harmónia, ellenpont: Vázlatok Kodály Zoltán poétikájához [Form, Harmony, Counterpoint: Essays on the Poetics of Zoltán Kodály] (Budapest: Rózsavölgyi, 2007), pp. 247-9.

39 Ernst Kurth, Musikpsychologie (Berlin: Max Hesse, 1931), Romantische Harmonik und ihre Krise in Wagners "Tristan" (Berlin: Max Hesse, 1920), and Grundlagen des linearen Kontrapunkts: Einführung in Stil und Technik von Bachs melodischer Polyphonie (Bern: Max Drechsel, 1917). Ligeti got to know Kurth's theories through the Kodály pupil András Szőllősy; see György Ligeti, 'Egy barátság kezdete' [The Beginning of a Friendship], Muzsika 39/3 (March 1996), p. 9.

40 Ligeti, 'Medvetánc', p. 252.

41 'Medvetánc', p. 252.

42 'Bartók Béla' in Zoltán Kodály, Visszatekintés II: Összegyüjtött írások, beszédek, nyilatkozatok [In Retrospect: Collected Writings, Speeches, Statements], ed. Ferenc Bónis (Budapest: Zenemúkiadó, 1964), pp. 426-34, at p. 430.

43 Ligeti/Conversation, pp. 47-8.

44 See Fosler-Lussier, Music Divided.

45 The invitation for the debate was published in volume 6/10 (October 1955), p. 28.

46 See, besides Ujfalussy, 'Számarányok', István Szelényi, 'Bartók zenéjének törvényszerüségei' [Regularities in Bartók's Music], UZSz 6/9 (September 1955), pp. 26-41; György Ligeti, 'Megjegyzések a bartóki kromatika kialakulásának egyes feltételeiröl' [Remarks on Bartók's Chromaticism], UZSz 6/9 (September 1955), pp. 41-4; Károly Sólyom, 'Lendvai Ernő “Tengelyrendszeréröl”' [About Ernő Lendvai's 'Axis Theory'], UZSz 6/12 (December 1955), pp. 1-11; Ernő Lendvai, 'Válasz Sólyom K. és Újfalussy J. cikkére' [Answer to the Articles of K. Sólyom and J. Újfalussy], UZSz 7/1 (January 1956), pp. 17-22; István Szelényi, 'Tengelyrendszer, tonalitás, atonalitás' [Axis Theory, Tonality, Atonality], UZSz 7/2 (February 1956), pp. 8-20; István Szelényi, 'Tengelyrendszer, funkció, Bartók zenéje' [Axis Theory, Function, Bartók’s Music], UZSz 7/3 (March 1956), pp. 19-23.

47 Lendvai, Bartók stílusa, p. 79.

48 Lendvai had hoped that he would be able to teach at the Academy of Music in Budapest. Instead, he became the director of a secondary school which specialized in music in the countryside.

49 Footnote in UZSz 6/9 (September 1955), p. 41.

50 Ligeti mentions that Kodály invited him to take part in folk music research. As he had an aversion to that, Kodály organized for him a post as a music theory teacher at the Academy of Music. Roelcke/Ligeti, p. 59.

51 György Ligeti, Klasszikus összhangzattan [Classical Harmony] (Budapest: Zenemúkiadó, 1954) and A klasszikus harmóniarend: Összhangzattani példák a barokk és a bécsi klasszikus zeneirodalomból [Harmonic Order in Classical Music: Examples From Baroque and Viennese Classical Music Literature] (Budapest: Zenemükiadó, 1956). 


\section{Anna Dalos}

52 Beckles Willson, Ligeti, Kurtág and Hungarian Music, p. 59.

53 György Ligeti, 'Über mein Concert Românesc und andere Frühwerke aus Ungarn', in GS II, pp. 151-3, at p. 152.

54 'Megjegyzések', p. 43, and 'Zur Chromatik Bartóks', p. 299.

55 Ligeti/Conversation, pp. 13-14.

56 'Megjegyzések', p. 43, and 'Zur Chromatik Bartóks', p. 299.

\section{Taylor \& Francis Not for distribution}

